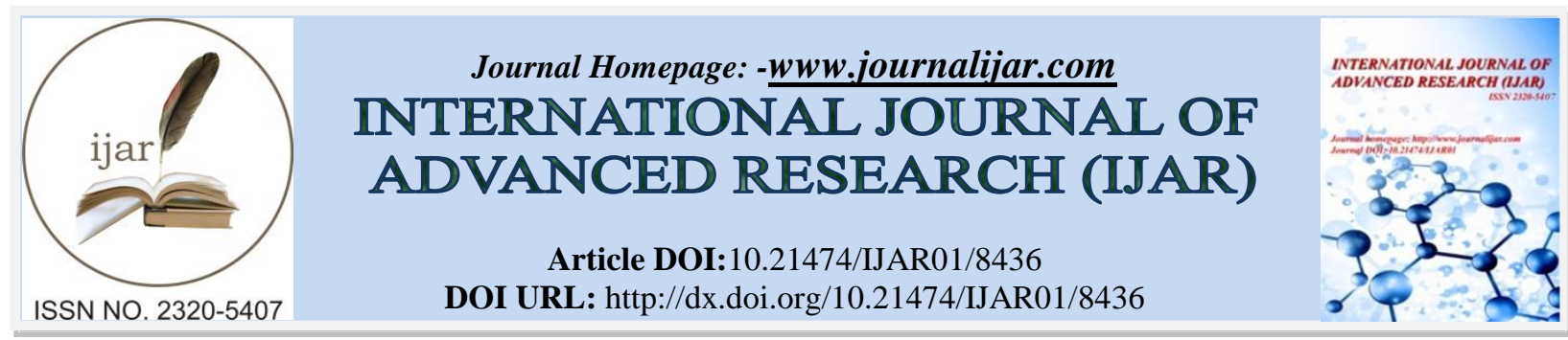

RESEARCH ARTICLE

\title{
WOMEN LEADERS:THEIR IMPACT ON MANAGEMENT INNOVATION IN EDUCATIONAL FIRMS.
}

\author{
Rana e.jisr $^{1}$, Kamel barbar ${ }^{2}$, Bassam hijazi ${ }^{2}$ and Radwan choughari ${ }^{1}$. \\ 1. Ass.prof, Jinan University, Tripoli - Lebanon. \\ 2. Prof, Jinan University, Tripoli - Lebanon.
}

\section{Manuscript Info}

Manuscript History

Received: 20 November 2018

Final Accepted: 22 December 2018

Published: January 2019

Keywords:-

Innovation, Women

Leadership,Transformational Leaders,

Transactional Leaders. Management innovation.

\begin{abstract}
Different studies on management innovation ,such as managerial activities, structures or practices, find it can be a source of competitive advantage. The current article is a review of management innovation at the organization level and examines the role of women leaders as a key antecedent. Due to its important role within organizations, women transformational and transactional leaders have a positive impact on management innovation. To be more precise, we focus on women leaders and examine transformational and transactional leadership. Additionally, as contextual variables such as level of education of the women leaders, may influence the effect of both styles of leadership, and management innovation,we examine its moderating role.Findings reveal that transformational and transactional women leaders contribute to management innovation.
\end{abstract}

Copy Right, IJAR, 2018,. All rights reserved.

\section{Introduction:-}

As competition increases and the speed of technology change quickens, organizations need to refurbish themselves. The challenge is not in producing new ideas to goods and services, but also in shifting the nature of management within organizations. This change occurs by adjusting organizational processes, structures and practices to beget an important source of competitive advantage (Teece, 2007). Old studies such as Chandler (1962) and, another more recent by Mol and Birkinshaw (2008) reveal the potential of innovation management to change in organizations and redefine a business by driving new ideas. Researchers have paid special attention towards

management as a productive ground for innovation ( Birkinshaw and Mol 2006; Birkinshaw et al., 2008). The latter defines management innovation as " the generation and implementation of a management practice, process, structure, or technique that is new to the state of the art and is intended to further organizational goals" (Birkinshaw et al., 2008,p.56). Hence, the term 'new' in this definition is related to management innovation. Some examples of management innovation are lean production developed by Toyota and brand management introduced by Procter \& Gamble (Mol and Birkinshaw,2008).

Innovation management is important for organizational performance, however, few studies have explained antecedents of management innovation (Birkinshaw and Mol,2006). Management innovation demonstrates a complicated way in which management work is performed in organizations. For example, management innovations rises without an infrastructure (such as research labs- that support technical innovation), and are intangible and imperceptible which result in ambiguity and complexity (Birkinshaw et al., 2008). This emphasizes the important

Corresponding Author:-Rana e.jisr.

Address:- Ass.prof, Jinan University, Tripoli - Lebanon. 
role of individuals in firms, or as Birkinshaw et al., (2008) find that "the critical role of human agency" (p.826) leading to a relevant role of leadership to management innovation.

The current study is considered as a contribution to the emergent dialogue on management innovation .We examine management innovation at the firm's level of analysis by concentrating on the search of management innovation that is novel to the organization, and examine women leadership behavior as a key antecedent of management innovation (Birkinshaw et al., 2008) which finds that the action of women leaders as an important factor leading to the pursuit of management innovation. Researchers have proposed that women leadership can motivate innovative thinking (Zhou and George, 2003), and have positively impacts the firm's choice (Finkelstein,1992). Since management innovation is an encompassing change in the way management performs, we consider women leadership as a distinguished issue in interpreting how firms introduce such a composite type of innovation. This study focuses on transformational and transactional women leadership and points towards how each type of women leadership behavior has an impact on the pursuit of management innovation in firms. Hence, this article enhances our understanding of the role of different women leadership styles and their influence of the pursuit of management innovation in firms.

This study is organized as follows. The next section is a review of the relevant literature and the developed hypotheses of the study. The other section presents the findings gained from the empirical analysis through a sample of SME's in different educational industries in Lebanon. The model is tested by using the Structural Equation Model Technique (SEM) developed by Joreskog (1967), which is known as the most general multivariate method. Furthermore, SEM is a causal model approach that can measure direct and indirect relationships in a certain model without random error. The research at hand, is conducted in different educational industries in Lebanon on a sample of women leaders. All constructs are borrowed from previous studies and measured on a 5-point rating Likert scale ( $I=$ never, sometimes, most of the time, always $5=$ frequently). Finally, a discussion is presented with the findings, implications, limitations, and recommendations for further research.

\section{Literature reviewand hypotheses \\ Leadership}

Exhaustive reviews and several studies of leadership have been conducted. A great-men theory emerged from the earliest studies of leadership. One postulationfor such a theory was that "to be a good leader one must be male and born to greatness" (Curry,2000, p.10). This view was limited to the social context that believes that a great leader is "the great leader must be born at the right moment in history in order for his leadership and greatness to be appreciated" ( Curry,2000,p.10). The great men theory deals with analysis of military or political leaders' biography. Greatness was assigned with leaders such as George Washington and Harry Truman. Curry (2000) postulated that this model is valued for its social context and the absence of women leaders and leaders of color. Maxine Greene wrote in Pathways to Leadership in Education the following:

"Women struggling to construct themselves as leaders have to cope with popular images of vulnerability, selfmastery, and a distinctively male confidence... Not only do would-be women leaders have to cope with the persistent images of male dominance, the only professional literature available to the women trying to master what is demanded of contemporary leadership consists largely ofinformation gathered by male policy-makers, presumed experts in theories ofleadership, and male administrators". (Curry, 2000, p. ix).

Schein (2001) finds that leadership is still more considered as a male quality. Furthermore, the literature points towards the presence of the male experience inside and outside of academia, while the leadership theory lacks the female perspective.

\section{Trait Theory}

Trait theory was an important approach to understand leadership in the earlier part of the $20^{\text {th }}$ century. "Leadership trait theory attempts to explain distinctive characteristics in leader effectiveness through the identification of a set of personal traits. It was assumed that potential leaders could be identified by observing and identifying personality traits" (Goff, 2003, p. 3).

These traits could be established and inherited in the personality of the individual. A revision of 124 studies to Stogdills (1948) created five leadership trait categories: (a) capacity, (b) responsibility, (c) achievement, (d) status, and (e) participation. Trait theory similar to the great-men theory, was one direction from leader to follower with the 
emphasis of the role of the leader (Stodgill, 1948). The findings of Stodgills (1948) studies were important in disproving trait theory:

"Leadership is not a matter of passive status, or of mere possession of some combination of traits. It appears rather to be a working relationship among members of a group, in which the leader acquires status through active participation and demonstration of his capacity for carrying cooperative tasks through completion". (p. 66)

\section{Transformational Leaders}

Transformational leadership emphasizes employees to reach organizational objectives by engaging in high-level needs for self-actualization (Cartwright,2010). According to Avolio (1999), there exist four dimensions to transformational leadership: (1) idealized influence; (2) intellectual stimulation; (3) inspirational motivation; and (4) individual consideration. Idealized influence includes charismatic behavior and is related to the extent where women leaders are trusted and admired. Intellectual stimulation stimulate followers to ask questions and be innovative. Inspirational motivation offers challenge to their followers, emphasizing team spirit between each other. Individual consideration demonstrates the extent to which followers' potential is established by satisfying the needs of the individuals as well as providing learning opportunities (Bass et al., 2003).In the role of the leader, some scholars refer to 'internal change agents' as a key element that plays a pivotal role in the pursuit of new styles in management innovation in organizations ( Caccaro et al., 2012). Moreover, Birkinshaw et al., (2008) confirm that leadership is not only related to management innovation, but also plays a pivotal role of human activity. Finally, Vaccaro et al., (2012) postulate that the positive relationship between transformational leadership and management innovation is considered. Thus, the first hypothesis of the study is:

Hypothesis 1 (H1):

Women transformational leadership is positively related to management innovation within the organization.

\section{Transactional Leadership}

The second style under examination is transactional leadership. Research scholars consider transactional conditional support as an important element for successful leadership performance. Den Hartog et al., (1997)find that there exist two dimensions to transactional leadership: contingent reward and active management. The first dimension refers to the compliance of followers to their leader in respect to praise, promotions, or rewards. Transactional conditional explains expectations and prefer appreciation when goals are achieved (Podsakoff and Skoy, 1982). Other researchers find that leaders are committed to certain 'contracts' within followers in contingent rewards (Bass andAvolio,1993). Such commitment might impede innovation (Amabile,1996;1998).

As to the second dimension, active management, it deals with the leader's interest to inspect any error in the follower's work. . "Such involvement underscores the way in which change agents, i.e. leaders, can drive the process of management innovation within the organization" (Vaccaro et al., 2012, p.34). Furthermore, Bass (1985) finds a relationship between clear objectives and related appreciation with good level of performance. The author distinguishes between transformational and transactional leadership and claims that "transformational leadership is more likely to reflect social values and to emerge in times of distress and change while transactional leadership is more likely to be observed in a well-ordered society" (p. 154). So, the second hypothesis of the study is:

Hypothesis $2(\mathrm{H} 2)$ : Women transactional leadership is positively related to management innovation within the organization.

\section{Women and Men Leadership}

Previous empirical research revealed three aspects of sex-related differences between women and men leadership. First, there is a difference in leadership style between men and women. A meta-analysis of more than 160 studies of sex-related differences demonstrated that women have a more participative or democratic style than an autocratic style than men do (Eagly and Johnson,1990). On the other continuum, other studies in performance, leadership and influence in teams revealthat men show a more self-confidence and less warmth with team members than women (Carli and Eagly,1999). Women more than men tend to adopt a transformational leadership style when mentoring followers (Eagly et al.,2003).

Second, women differ from men on leadership behavior. Numerous studies using 360 degree feedback processes reveal that women managers mark higher than men on teamwork, knowledge sharing, and care for employees ("As 
leaders",2000). Other studies of leadership demonstrate that women are more aware of their emotions, and demonstrate more empathy whereas men are more optimistic, adaptable, and can manage stress (Goleman,1998).

Third, a meta-analysis of 82 studies measuring leadership effectiveness reveal that men and women leaders do not differ in effectiveness, which means that followers favor men when the setting is male-dominated and vice versa ( Eagly et al., 1995).

\section{Management Innovation: Definition}

One definition for management innovation came as the "generation and implementation of a management practice, process, structure or technique that is new to the state of the art and is intended to further organizational goals" ( Birkinshaw et al., 2008,p.829). It points to important changes done by managers, but are hard to imitate, hence more likely to lead to competitive advantage and increased competitiveness (Hamel, 2007). Management innovation deals with changes in managers' directions, motivating people and coordinating of activities (Hamel,2006). Such changes are embedded in the organization as management innovation establishes itself through processes, structures or management practices. Birkinshaw et al., (2008) classify management innovation into four different perspectives: fashion, institutional, rational, and cultural perspective. In the same vein of thoughts, the current paper deals with management innovation with respect to the rational perspective. Such perspective finds that new practices, processes, or structures are introduced by individuals inside the organization to enhance its performance.

Birkinshaw et al., (2008) refer to 'two equally valid points of view' (p.828) vis-à-vis the originality of management innovation, namely 'new to the state of the art' and 'new to the organization'. In these two cases, the level of analysis is management or indeed the world. As to the 'new to the organization', the level of analysis is the organization itself which enables us to empirically test a series of hypotheses at the organization level. While management innovation deals with a high level of uncertainty, the introduction of management innovation, which is novel to the firm, deals with uncertainty too. To have management innovation, the change should cover new ways of managing by means of new processes, practices, or structures, including specific techniques. Self-managed teams is an example of management innovation where such teams are responsible for their functioning, setting of priorities, and decision making in the firm (Bunderson and Boumgarden,2010). Self-managed teams at Procter \& Gamble illustrate change in the three aspects of management innovation; processes, practices and structure (Waterman,1998).Management processes discusses the routines that manage the work of managers since employees are responsible for setting their objectives and deciding for activating their tasks (Birkinshaw,2008).Management practices discuss the responsibilities of managers as a part of their daily work, setting objectives, arranging activities and functions ( Birkinshaw et al., 2008).Finally, Organizational structure discusses how firms arrange communication, and align effort from their employees ( Birkinshaw et al., 2008).

\section{Leadership and Management Innovation: The moderating role of education}

Following Birkinshaw et al., (2008) work on the role of an individual in management innovation, we focus on the action of individuals inside the firm by aiming to leaders in general and women leaders in specific.Due to their noticeable role in organizations, leaders have a great impact on organizational conditions where management innovation can be created and implemented ( Crossan and Apaydin,2010).For example, leaders have been noticed that they have a noticeable impact on organizational performance ( Finkelstein, 1993).According to Elenkov et al., (2005), there are different ways in which leaders can affect innovation within the organization through their prominent position. Furthermore, leaders can positively affect innovation in organizations by reducing complexity and uncertainty and by connecting a shared vision, maintaining change and fostering a certain kind of culture (Birkinshaw et al., 2008). Similarly, Marion and Uhl-Bien (2001) find that leaders may play a pivotal role in simplifying complex dynamics within firms. This means that leaders may help subordinates understand the ambiguous changes and facilitate guidance.

The role of leadership is important in employee willingness to spread ideas and to improve the performance of the organization (Detert and Burris,2007). To understand how a precise leadership behavior influences management processes, practices and structures, we examine transformational and transactional women leadership. Drawing of the work of Vaccaro et al., (2012) on leadership behaviors, transformational and transactional leadership have been examined in various studies to understand the extent to which leaders affect innovation management in organizations. Building on this important role, we developed hypotheses about how transformational and transactional women leadership affect innovation management. Furthermore, this paper focuses on the level of education as contextual variable, as the latter has been considered to capture the scope of operations in the 
organization. We argue that level of education of women leaders is a key contextual variable in studying innovation management since it is related to the intricacy achieving as a key variable for innovation and creative thinking in organizations (Nonaka, 1994; Leonard and Sensiper,1998; Scholl, 2010).So, the third hypothesis of the study is:

Hypothesis $3(\mathrm{H} 3)$ : The level of education of women leaders moderates the relationship between transformational leadership and management innovation such that increased women education strengthen the positive effect of transformational leadership upon management innovation.

Hypothesis $4(\mathrm{H} 4)$ : The level of education of women leaders moderates the relationship between transactional leadership and management innovation such that increased women education strengthen the positive effect of transactional leadership upon management innovation.

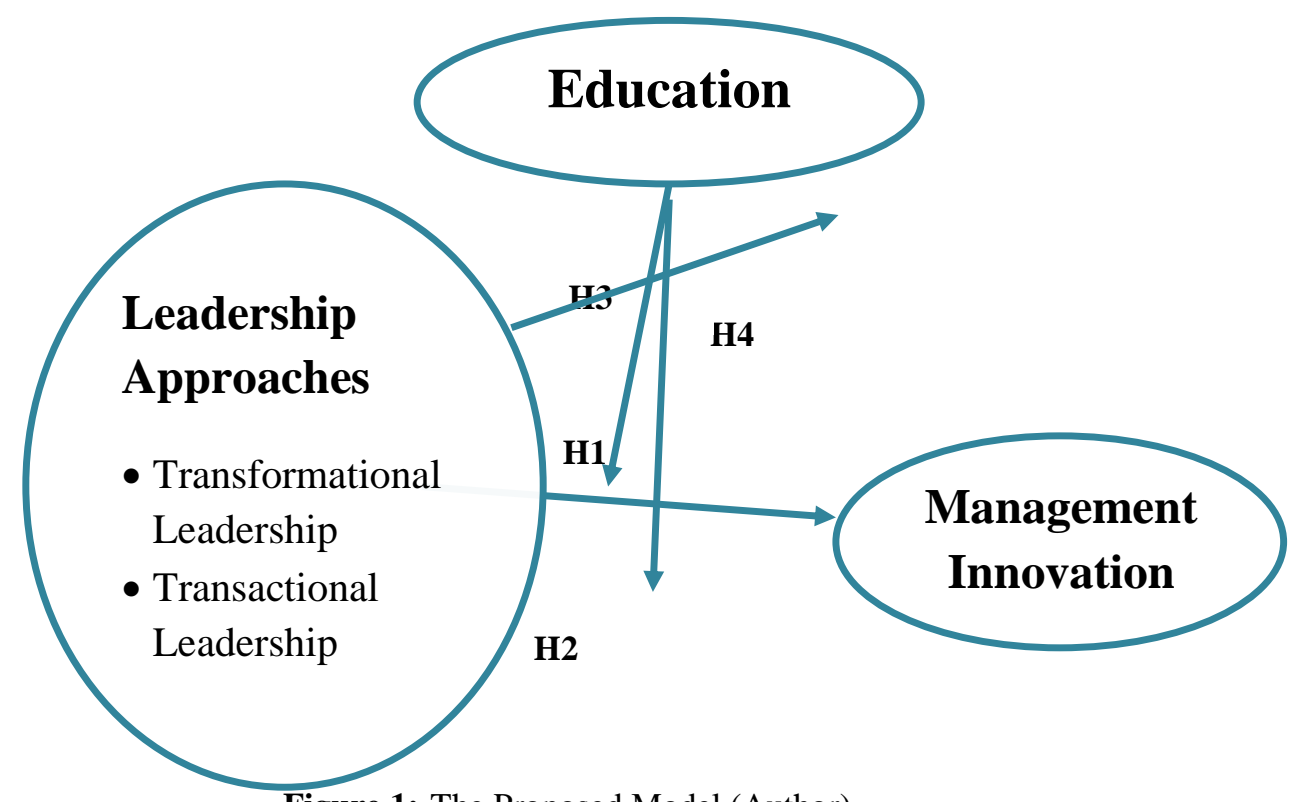

Methods:-

Figure 1:-The Proposed Model (Author)

\section{Sample and Measures}

The sample of the current study is composed of women leaders from different educational organizations in Lebanon. The sample covered a broad range of educational firms and was restricted to privately held firms with at least 100 employees. Multi-item scales are borrowed from previous studies. Cronbach's alpha was measured to assess reliability of the scales. The structure of the instrument is examined using confirmatory factor analysis (CFA).Moreover, women leaders are asked to fill a questionnaire with 12 items using a 5-point Likert scale anchored by "strongly disagree" and "strongly agree". The number of respondents is 100 women leaders from different educational institutions in Lebanon.

\section{Transformational leadership}

This construct is measured by the Multifactor Leadership Questionnaire [MLQ] scale developed by Bass \& Avolio, (1990). The transformational leadership scale includes 4 items. All items are answered using a five-point response anchor ranging from 1(Never) to 5 (Always). Confirmatory factor analysis is conducted to validate the scale. $\left(\mathrm{x}^{2} \mathrm{I}\right.$ $\mathrm{df}=2, \mathrm{RMSEA}=.051, \mathrm{NFI}=.957, \mathrm{NNFI}=.955, \mathrm{CFI}=.985)$. As to validity and reliability, the scale reveals a good result $(\alpha=.641)$.

\section{Transactional leadership}

Transactional Leadershipis measured by the Multifactor Leadership Questionnaire [MLQ] scale (Bass \& Avolio, 1990). The scale includes 4 items and is answered using a five-point response anchor similar to transformational leadership scale. Results of confirmatory factor analysis $\left(\mathrm{x}^{2} \backslash \mathrm{df}=1\right.$, RMSEA $=.090, \mathrm{NFI}=.987$, NNFI $=.907$, CFI $=$ $.991)$. As to reliability, the scale reveals an acceptable result $(\alpha=.661)$. 


\section{Management innovation}

Management innovation is measured by a scale developed by Vaccaro et al., (2012). The scale includes 4 items. Results of confirmatory factor analysis $\left(\left(x^{2} \backslash \mathrm{df}=1\right.\right.$, RMSEA=.072, NFI=.991, NNFI=.976, CFI $=.994$. The scale reveals a reliability of $\alpha=.746$ and explains the demonstration of management innovation in developing new rules, regulation, practices and procedures. Items Variables 1and 2 (management rules and activities) deal with new rules of managers. Items 3 and 4 are concerned in work performance and how rewards are engendered. In general, the current scale deals withdifferent aspects of management innovation, aiming towards managers' activities,and the organizational context where work is done.

\section{Study Analysis}

The study at hand is analyzed by using the Structural Equation Model (SEM) to assess the fit of the hypothesized model using AMOS 21 program. Schumacker and Lomax (2004) find that there are four important reasons to use SEM to measure the hypothesized model fit. "The first reason is that, in the past, researchers used to measure a limited number of variables and the basic statistical models were sufficient. Today, researchers need to examine multiple observed variables in order to realize the best part of their scientific inquiry. The second reason is that SEM considers observed and latent variables, as well as measurement error while analyzing data. The third reason is the maturity of SEM within the last 30 years and its ability to analyze a number of complex theoretical models. Finally, SEM software is user-friendly today, thus it is easy to learn via textbooks, workshops, or courses" (Jisr, 2015, p. 80).

The fit indices that are used to measure the model in the study at hand are $\mathrm{x}^{2} \backslash \mathrm{df}, \mathrm{CFI}, \mathrm{NFI}, \mathrm{NNFI}$, and RMSEA. The acceptable fit for CFI, NFI, and NNFI is 0.90 or more. The chi-square test is the assessment of fit of a specific model and a comparison between two models $\mathrm{x}^{2}<0.05$ (Hair et al., 1998). RMSEA measures the approximate fit. According to Kline, R.B. (2005), values less than 0.08 designate satisfactory fit, and values less than 0.05 designate close fit (Kline, R.B. 2005).

\section{Results:-}

The conducting results of the current study reveal descriptive statistics and correlation between the different variables and are presented in Table 1 below.

\begin{tabular}{|c|c|c|c|c|c|c|}
\hline Variables & Mean & SD & & 1 & 2 & 3 \\
\hline Transformational Leadership & 4.77 & 1.426 & & & & \\
\hline Transactional Leadership & 1.53 & 2.11 & $\begin{array}{l}\text { Rig. } \\
\text { pig. }\end{array}$ & $\begin{array}{l}0.288^{* *} \\
.000\end{array}$ & & \\
\hline Education & 4.52 & 1.05 & pig. & $\begin{array}{l}.391^{* * *} \\
.000\end{array}$ & $\begin{array}{l}.366^{* * *} \\
.000\end{array}$ & \\
\hline Management innovation & 1.31 & 1.9 & pig. & $\begin{array}{l}.366^{* * *} \\
.000\end{array}$ & $\begin{array}{l}.353^{* *} \\
.000\end{array}$ & $\begin{array}{l}447^{*} \\
000\end{array}$ \\
\hline
\end{tabular}

Table 1:-Mean, standard deviation, and correlation $(* * p<0.01)$

Table 2 below presents the total effects with the direct and indirect effect and the level of significance between the predictor as well as the dependent model of the study. The results reveal that the two hypotheses $\mathrm{H} 1$ and $\mathrm{H} 2$ are supported. This means that transformational and transactional leadership are positively related to innovation management.

Furthermore, the 4 variables of transformational leadership explain more than $76 \%$ of variance. Also, the 4 variables of transactional leadership explain more than $50 \%$ of the variance. The 4 variables of management innovation explain more than $65 \%$ of the variance.

As to the hypotheses of the study, transformational leadership reveals a direct effect on management innovation $(\beta=$ .53). Again, transactional leadership reveals a direct relationship on management innovation $(\beta=.25)$. As to education, the moderator, the results reveal an indirect effect on transformational and transactional leadership consecutively $(\beta=.53)$ and $(\beta=.54)$, and an indirect effect on management innovation $(\beta=.54)$. In addition, there is a third hypothesis that suggests a moderation(education) between transformational and transactional leadership with management innovation. Table 2 shows a positive effect of transformational leadership on management innovation in the presence of the moderator (education). This result leads to state that $\mathrm{H} 3$ is supported. 


\begin{tabular}{|c|c|c|c|c|}
\hline Path & $\begin{array}{l}\text { Direct } \\
\text { effect }\end{array}$ & $\begin{array}{l}\text { Indirect } \\
\text { ffect }\end{array}$ & $\begin{array}{l}\text { Total } \\
\text { effect }\end{array}$ & $\mathbf{R}^{2}$ \\
\hline From transformational leadership to management innovation & $.53^{* * *}$ & -- & $.53^{* * *}$ & 0.13 \\
\hline From transactional leadership to management innovation & $.25^{* * *}$ & -- & $.25^{* * *}$ & 0.54 \\
\hline From education to transformational leadership & -- & $.53^{* * * *}$ & $.53^{* * * *}$ & 0.21 \\
\hline From education to transactional leadership & & $.51^{* * * *}$ & $.51^{* * *}$ & 0.13 \\
\hline From education to management innovation & -- & $.54^{* * * *}$ & $.54^{* * * *}$ & 0.34 \\
\hline
\end{tabular}

Table 2:-Structural model results (direct, indirect, total effects, and $\mathrm{R}^{2}$ )

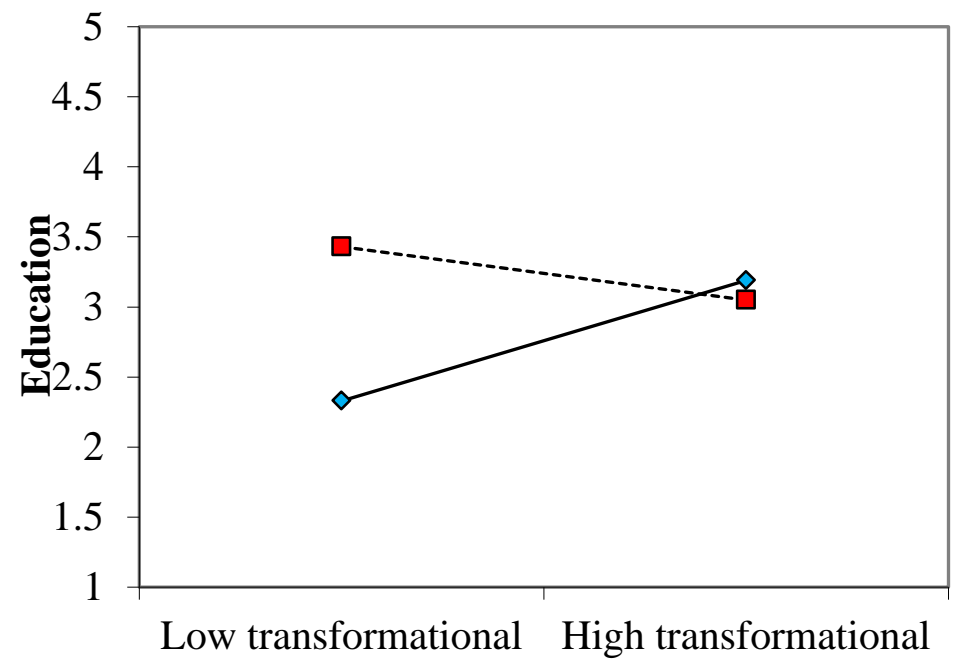

Figure 2:-Effect of interaction between transformational leadership and education on management innovation (low education in blue arrow and high education in redarrow)

The plot in figures 2 and 3reveal that when the moderator (education) is low, there exists a positive relationship between transactional leadership and management innovation. On the contrary, when the moderator is high, there exists a negative relationship between transactional leadership and management innovation. This leads to say that education dampens the relationship between transactional leadership and management innovation. Thus, H4 is supported.

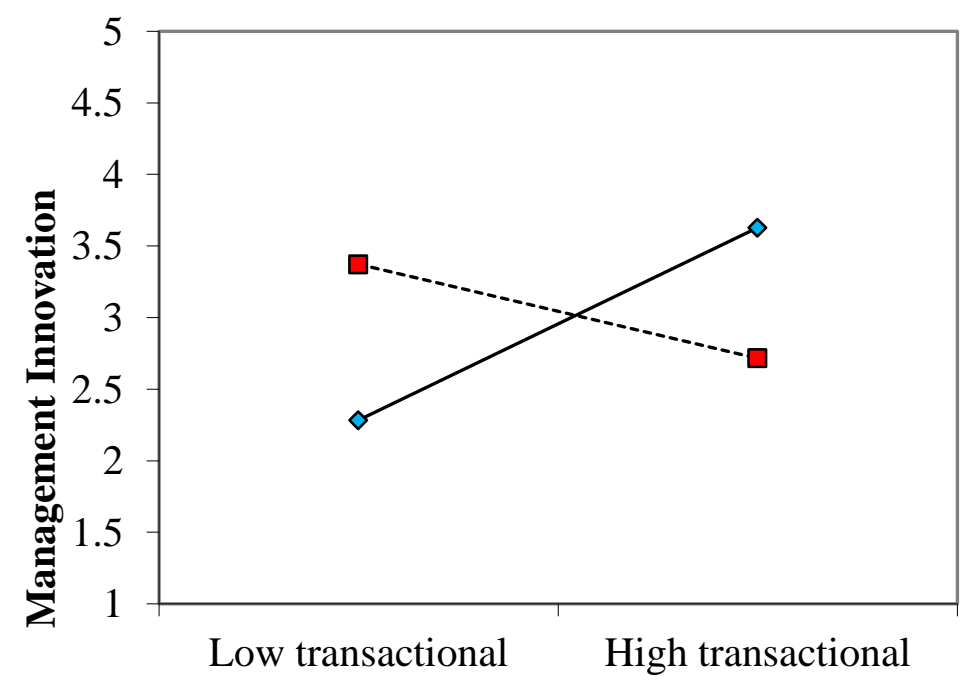

Figure 3:-Effect of interaction between transactional leadership and education on management innovation. 


\section{Discussion and Conclusion:-}

Actually, many studiesare considering the crucial role of innovation in firms. Nevertheless, new insights into management innovation should be examined too. The current section aims towards discussing the results of the study and discussing the contribution to the literature of leadership as well as to the literature of management innovation. Our study contributes to new perceptions with respect to the effect of transformational and transactional leadership behaviors on management innovation. Moreover, the current study shows the effectiveness of these leadership behaviors and itsrelationship to the level of education of the woman leader. As stated by Hambrick and Mason (1984) many years ago, women leaders are very important actors in organizations and are internal agents who are responsible for implementing practices and processes. In addition, Jisr and Maamari (2018) findthat leadership has a direct relationship on management innovation. Also, we provide a good evidence that women leaders alsohave the same direct relationship with management innovation, including the moderating effect of women leaders' education.

The current study carries certain limitations. Our model cannot include all possible variables. This indicates that there exist more contingency variables influencing management innovation than the ones we have integrated in our study. However, our study offers a foundation for further research studies. Another possible limitation and point of criticism may be the size of the sample. This however, can be overcome by testing the model on a larger sample and in different context.

\section{References:-}

1. Avolio, B.J. (1999), Full leadership development: Building the vital forces in organizations, Thousand Oaks, CA: Sage.

2. Bass, B.M. (1985), Leadership and performance beyond expectations, New York: Free Press.

3. Bass, B.M., \& Avolio, B.J. (1990). Transformational leadership development: Manual for themultiactor leadership questionnaire. Palo Alto, CA: Consulting Psychologists Press

4. Bass, B. M., Jung, D. I., Avolio, B. J. and Berson, Y. (2003). 'Predicting unit performance by assessing transformational and transactional leadership'. Journal of Applied Psychology, 88, 207-18

5. Birkinshaw, J., Hamel, G. and Mol, M. J. (2008). 'Management innovation'. Academy of Management Review, 33, 825-45.

6. Birkinshaw, J. and Mol, M. J. (2006). 'How management innovation happens'. MIT Sloan Management Review, 47, 81.

7. Birkinshaw, J., Hamel, G. and Mol, M. J. (2008). 'Management innovation'. Academy of Management Review,33, 825-45.

8. Bunderson, J. S. and Boumgarden, P. (2010). 'Structure and learning in self-managed teams: why "bureaucratic" teams can be better learners'. Organization Science, 21, 609-24.

9. Carli, L. L., \& Eagly, A. H. (1999). Gender effects on social influence and emergent leadership. In G. N. Powell (Ed.), Handbook of gender and work (pp. 203-222). Thousand Oaks, CA: Sage.

10. Chandler, A. D. (1962). Strategy and Structure: Chapters in the History of the Industrial Enterprise. Cambridge, MA: MIT Press.

11. Crossan, M. M. and Apaydin, M. (2010). 'A multi-dimensional framework of organizational innovation: a systematic review of the literature'. Journal of Management Studies, 47, 1154-91.

12. Curry, B. K. (2000). Women in power: Pathways to leadership in Education. New York, NY: Teachers College Press.

13. Den Hartog, D. N., Van Muijen, J. J. and Koopman, P. L. (1997). 'Transactional versus transformational leadership: an analysis of the MLQ'. Journal of Occupational and Organizational Psychology, 70, $19-34$.

14. Detert, J. R. and Burris, E. R. (2007). 'Leadership behavior and employee voice: is the door really open?'. Academy of Management Journal, 50, 869-84.

15. Eagly, A. H., \& Johnson, B. T. (1990). Gender and leadership style: A meta-analysis. Psychological Bulletin, $108,233-256$.

16. Eagly, A. H., Karau, S. J., \& Makhijani, M. G. (1995). Gender and the effectiveness of leaders: A metaanalysis. Psychological Bulletin, 117, 125-145.

17. Eagly, A. H., Johannesen-Schmidt, M. C., \& van Engen, M. (2003). Transformational, transactional, and laissez-faire leadership styles: A meta-analysis comparing women and men. Psychological Bulletin, 129, 569591.

18. Eagly, A. H., \& Johnson, B. 
19. Elenkov, D. S., Judge, W. and Wright, P. (2005). 'Strategic leadership and executive innovation influence:an international multi-cluster comparative study'. Strategic Management Journal, 26, 665-82.

20. Finkelstein, S. (1992). 'Power in top management teams: dimensions, measurement, and validation'. Academy of Management Journal, 35, 505-38.

21. Finkelstein, S. (1993). 'Top management team size, CEO dominance, and firm performance: the moderating roles of'. Academy of Management Journal, 36, 844-63.

22. Goleman, D. (1998). Working with emotional intelligence. New York: Bantam Books.

23. Goff, D. G. (2003). What do we know about good community college leaders: A study in leadership trait theory and behavioral leadership theory. Retrieved from http://www.eric.ed.gov/contentdelivery/servlet/ERICServlet?accno=ED47645600000aacb361\&acdnat=135266 0180_58274f188a39a834f048266e1a3a3d8a.

24. Hair,J.F.Jr. Anderson,R.E.,Tatham,R.L. and Black,W.C., (1998), Multivariate Data Analysis, $5^{\text {th }}$ edition, Upper Saddle River, Prentice-Hall, New Jersey.

25. Hamel, G. (2006). 'The why, what, and how of management innovation'. Harvard Business Review, 84, 72-84.

26. Hamel, G. (2007). The Future of Management. Boston, MA: Harvard Business School Press.

27. Hambrick, D. C. and Mason, P. A. (1984). 'Upper echelons: the organization as a reflection of its top managers'. Academy of Management Review, 9, 193-206.

28. Jisr, R.(2015),Knowledge,effectuation,and innovation performance: The case of a lebanese media company.

29. Jisr,R., and Maamari, (2018). Transformational and transactional leadership with effectuation, (in the press).

30. Kline, R.B., (2005), Principles and Practice of Structural Equation Modeling, $2^{\text {nd }}$ edition, Guilford Press, New York.

31. Leonard,D., and Sensiper,S.( 1998).The role of tacit knowledge in group innovation.California Management Review,40,112-132.

32. Marion, R. and Uhl-Bien, M. (2001). 'Leadership in complex organizations'. Leadership Quarterly, 12, 389418.

33. Mol, M. J. and Birkinshaw, J. (2008). Giant Steps in Management: Innovations that Change the Way We Work. Dorchester: FT Prentice Hall.

34. Nonaka,I.(1994),A dynamic theory of organizational knowledge creation.Organization Science,5,14-37.

35. Schein, V. E. (2001). A global look at psychological barriers to women's progress in management. Journal of Social Issues, 57, 675-688.

36. Schumacker,R.E. and Lomax,R.G. ., (2004), A Beginner's Guide to Structural Equation Modeling, $2^{\text {nd }}$ edition.

37. Scholl,W.(2010),Innovationen:Wie Organizationen neues Wissen produzieren und etablieren. In H. Hof (Ed.),Innovations: Vol.1 Innovationsforschung.Berlin,Germany: Lit-Verl.

38. Stogdill, R. M. (1948). Personal factors associated with leadership: A survey of the literature. Journal of Psychology, 25, 35-71.

39. Teece, D. J. (2007). 'Explicating dynamic capabilities: the nature and microfoundations of (sustainable) enterprise performance'. Strategic Management Journal, 28, 1319-50.

40. Vaccaro,I.G., Jansen,J.P.,Bosch,V.D.( 2012),Management Innovation and Leadership: The moderating role of Organizational Size,Rotterdam School of Management,Erasmus University

41. Waterman, R. H. (1998). What America Does Right: Learning from Companies that Put People First. New York:

42. W. W. Norton \& Co.

43. Zhou, J. and George, J. M. (2003). 'Awakening employee creativity: the role of leader emotional intelligence'. Leadership Quarterly, 14, 545-68. 